\title{
The effect of the researchers, research and development expenditure as innovation inputs on patent grants and high-tech exports as innovation outputs in OECD and emerging countries especially in BRIICS
}

\author{
Metin Gürler ${ }^{1 *}$ \\ 1* Istanbul Medipol Unıversity, Faculty of Busıness Adm. and Man. Sciences, İstanbul, Turkey (ORCID: 0000-0002-9263-0258) metin.gurler@medipol.edu.tr
}

(International Conference on Design, Research and Development (RDCONF) 2021 - 15-18 December 2021)

(DOI: 10.31590/ejosat.1051899)

ATIF/REFERENCE: Gürler, M. (2021). The effect of the researchers, research and development expenditure as innovation inputs on patent grants and high-tech exports as innovation outputs in OECD and emerging countries especially in BRIICS. European Journal of Science and Technology, (32), 1140-1149.

\begin{abstract}
According to the correlation tests (Pearson Correlation and Spearman's rho) analysis with the cross-section data for forty-eight countries of OECD and some emerging countries including BRIICS countries, R\&D expenditures, patents and FDI have high positive effect on high-tech exports and there is a low positive relationship with high-tech exports and researchers. For causality analysis of raw data with Granger causality test it is seen that only researchers does Granger cause R\&D. For Toda Yamamota causality test (Wald test) patents and FDI cause high-tech exports. R\&D and researchers cause patents too. It can be said that researchers and R\&D end up with patent grants and patents will cause an increase in high-tech exports. The results of the OLS does show an adequate relationship between hightech exports and patents, between R\&D expenditures and FDI while high-tech exports and researchers do not have.
\end{abstract}

Keywords: High-tech exports, Research \& Development (R\&D), Patents, Innovation, FDI

\section{OECD ve BRIICS ülkeleri başta olmak üzere gelişmekte olan ülkelerde araştırmacıların ve Ar-Ge harcamalarının inovasyon çıtıları olarak patent tescillerine ve yüksek teknoloji ihracatına etkisi}

$\ddot{O} \mathbf{z}$

OECD ve BRIICS ülkeleri de dahil olmak üzere on gelişmekte olan ülkeler için 2020 yılı verileri ile yapılan korelasyon testleri (Pearson Correlation ve Spearman's rho) analizine göre, Ar-Ge harcamaları, patentler ve DYY'nin yüksek teknoloji ihracatı ile yüksek derecede bir ilişkisi var iken, yüksek teknoloji ihracatı ve araştırmacılar arasında düşük bir pozitif ilişki vardır. Ham verilerin Granger nedensellik testi ile yapılan analizde sadece araştırmacıların Ar-Ge'ye neden olduğu görülmektedir. Toda Yamamota nedensellik testi (Wald testi) sonucuna göre patentler ve DYY yüksek teknoloji ihracatına neden olur. Ar-Ge ve araştırmacılar da patentlere neden oluyor. Araştırmacıların ve Ar-Ge'nin patent tescili ile sonuçlanması ve patentlerin de yüksek teknoloji ihracatında artışa neden olacağı söylenebilir. EKK sonuçları, yüksek teknoloji ihracatı ve patentler arasında, Ar-Ge harcamaları ile DYY arasında yeterli bir ilişki olduğunu gösterirken, yüksek teknoloji ihracatı ve araştırmacılar arasında bulunmadığını göstermektedir.

Anahtar Kelimeler: Yüksek teknoloji ihracatı, Araştırma ve Geliştirme (Ar-Ge), Patentler, İnovasyon (Yenilik), DYY

* Corresponding Author: ozlem.ozsoy@gmail.com; ozlemozsoy1978@gmail.com 


\section{Introduction}

In his book "Capitalism, Socialism and Democracy" Schumpeter (1942) emphasized the innovation as the impulse that sets and keeps the capitalist engine in motion comes from the new consumers' goods, the new methods of production or transportation, the new markets, the new forms of industrial organization that capitalist enterprise creates.

In his book "Capitalism, Socialism and Democracy", Schumpeter (1942), describes the innovation as the new consumer goods, new methods of production or transportation, new markets, and new forms of industrial organization created by capitalist enterprise. Innovation is important not only for firms but for the whole country to compete with other firms and countries in international markets. It is also driven force of the development of a country.

During industrialization, basic inputs such as labour coming from rural to urban (cities) and capital accumulation that was a result of citizens' saving or other countries' investments (Foreign Direct Investment, FDI) and loans are key determinants of growth at the initial level of development for emerging countries.

In today's world, where the competition has spread from the country level to the regions, cities and even to enterprises, a country has to create an environment where the firms can comfortably make their production, designs and innovations and export their competitive products and services in the international markets. Competitive thoughts should start from the individual firm level and spread throughout the country. By prioritizing investment in human capital a creative generation should be achieved, the innovation competence of the private sector should be encouraged, and if there is a lack of firms' entrepreneurship in $\mathrm{R} \& \mathrm{D}$ the public should lead the private sector in $\mathrm{R} \& \mathrm{D}$ in order to become a technology producing country rather than a technology importer and user (Gürler, 2016). The exit from the Middle Income Trap will not be possible by investing more capital, but only with new technological progress through $R \& D$, education and institutional innovation (Yeldan et al., 2012).

In their article, Aghion and Howitt (1992) proposed an economic growth model influenced by Schumpeter's creative destruction process, and they argued that growth was due only to technological progress and that this would arise from competition among innovative research firms. Each innovation consists of a new intermediate that can be used to produce the final output more efficiently than before. Research firms are motivated by the expectation of monopoly profits that can be obtained when a successful innovation is patented. But these profits will be destroyed by the next innovation, which will make the existing intermediate good obsolete.

The World Bank (2021a) defines the high-tech exports as the products with high R\&D intensity, such as aerospace, computers, pharmaceuticals, scientific instruments and electrical machinery. Eurostat (2021a) uses a compilation of the manufacturing industry by technological intensity and based on NACE Rev.2 for hightech economic activities and classifies products as high-tech, midhigh-tech, medium-low-tech and low-tech. As Eurostat (2021a), the OECD (2009 and 2011) has developed a four-way classification of exports - such as high, medium-high, mediumlow and low-technology. To describe the high-tech exports, OECD has taken into consideration the expenditures on R\&D relative to the gross output and value added of different types of e-ISSN: 2148-2683 industries that produce goods for export. Aircraft, computers, and pharmaceuticals are the examples of high-technology industries; motor vehicles, electrical equipment and most chemicals are medium-high-technology; rubber, plastics, basic metals and ship construction are medium-low-technology; food processing, textiles, clothing and footwear are low-technology industries. OECD classification is used in this study to calculate the hightech exports of the country set. OECD classification is based both on direct $\mathrm{R} \& \mathrm{D}$ intensity and $\mathrm{R} \& \mathrm{D}$ embodied in intermediate and investment goods proposed in Hatzichronoglou (1997).

In a competitive country business enterprises make $R \& D$ and lead innovative products and processes. They produce sophisticated goods and services so that they export them to other countries which need. By exporting high-tech products, they take place in global value chains and supply chains.

$\mathrm{R} \& \mathrm{D}$ expenditure is one of the important indicators of innovation of firms and countries. $R \& D$ is directly linked to innovation through new products and new processes and indirectly to know-how (OECD, 2009). OECD (2017) describes $\mathrm{R} \& \mathrm{D}$ as basic research, applied research and experimental development (new products or processes).

$\mathrm{R} \& \mathrm{D}$, innovation and patents are the main topics of the firms and countries in post-industrialization era. Companies achieve competitiveness through innovation activities (Porter, 1990). Countries are divided into 4 groups according to their development stages as factor driven, investment driven, innovation driven and wealth driven (Porter 1998). The World Economic Forum (WEF), who issues the Global Competitiveness Index based on Porter's views, has divided countries into 3 main groups according to their development stages as factor driven, efficiency driven and innovation driven countries (WEF, 2006). In the first stage of the development, the economy is mostly based on the primary factor endowments such as unskilled labour and natural resources and these countries are classified as factordriven countries. As the industrialization starts in the country, country becomes more competitive with increasing productivity and development it will cause a raise in wages. These countries on the way of industrialization stage of development are called as the efficiency-driven countries. These countries should be moreefficient and productive to maximize their profits as the wages have risen and they cannot increase prices. In the final stage after industrialization the revenues will only compensate the rising wages and rent of the invested capital. The countries should make R\&D expenditures, and get patents to achieve more sophisticated products and production processes as a result of innovation. The countries at this final stage of the development are called as innovation-driven countries (WEF, 2017).

Invention, innovation and patents are related topics. In a patent there msut be an exclusive right granted to an invention. This inevntion may either be a product or process that provides a new method to the existance or offers a new technical solution to solve a problem. In a patent application, the technical information about the invention must be disclosed to the public (WIPO, 2021a).

Many enterprises make R\&D for innovation and some of them even have higher patent grants than some countries' total patent grants. Huawei Technologies Co., Ltd. ( China), Samsung Electronics Co., Ltd. (Republic Of Korea), Mitsubishi Electric Corporation (Japan), LG Electronics Inc.( Republic Of Korea) and Qualcomm Incorporated (U.S.) are top Patent Cooperation 
Treaty (PCT) applicants In 2020 according to a report issued by WIPO (2021b).

\section{Methodology}

In this study, the relationship between FDI, researchers, R\&D expenditures as a share of Gross Domestic Products (GDP), patent grants and high-tech export was analysed for 38 OECD countries and ten emerging markets where six of them were BRIICS countries for 2020 and most recent year.

The data for researchers, $R \& D$ and patents were collected from the WIPO (2021c), the World Bank (2021b), OECD (2021), UIS (2021), TURKSTAT (2021), and the Eurostat (2021b). The data for FDI was from UNCTAD (2021) and the data for exports was collected from TradeMap (2021) for 2020 and most recent year. The high-tech export data was calculated according to the study of the OECD (2011).

\subsection{Country selection}

In the study totally 48 countries were analysed. Thirty-eight of them are OECD members and six countries are members of BRIICS and the rest four countries are as; Malaysia, Singapore, Taiwan (Chinese Taipei) and Viet Nam.

We analysed our country set considering the indicators which were related with innovation inputs and outputs as:

- High-tech exports (million \$, 2020), high-tech exports are calculated by OECD (2011) classification,

- Total patent grants (direct and PCT national phase entries, resident and abroad, 2020),

- R\&D as a share of $\operatorname{GDP}(\%, 2020)$,

- Researcher per thousand employment,

- FDI (million \$, inward stock, 2020).

\subsection{Data selection}

As the mentioned above there was a lack of data for the indicators listed above for some countries for some years, crosssection data analysis was made rather than panel data analysis. Data for the indicators were gathered for 2020 and the most recent year. The natural logarithm (ln) of the data were also taken and used in the analysis as the data used in the study for the countries were from different sources and in different units.

The 22nd version of the Statistical Package for Social Sciences Data (SPSS software, IBM Corp., Armonk, NY, USA 2021a) was used to evaluate and analyse the descriptive statistics of the data, and to test the normality of the data, and to show the relationship between the indicators by the scatter diagrams. The 9th version of the EViews software (QMS, Emeryville, California, United States 2021) was used to obtain the ordinary least squares (OLS) regressions to analyse the relationships between indicators with statistical tests of causality.

Checking the reliability and normality of the data is very important during statistical analysis. Jarque-Bera (JB) test, Shapiro-Wilks (SW) test and Kolmogorov-Smirnov (KS) test are common tests which were used to analyse the normality of the data. As the number of the countries in the study is less than 50, the Shapiro-Wilk test is more appropriate method to be used for testing the normality of the data set (Mishra et al. 2019). According to the normality tests, parametric tests should be applied for the normally distributed data set and non-parametric tests should be used for non-normally distributed data set. Some parametric tests are such as the Student's t-tests, one-wayANOVA (analysis of variance) and the Mann-Whitney-Wilcoxon (MWW) test or the Wilcoxon test, Kruskal-Wallis tests are the common non-parametric statistics for ((IBM 2021b; Minitab 2015).

For testing the normality of the data, the hypotheses are as:

$\mathrm{H}_{0}$ : The data set statistically distributed normal

$\mathrm{H}_{1}$ : The data set statistically distributed not normal

For a given data, if the probability value $(\mathrm{p})$ is greater than the critical value $(\mathrm{p}=0.05)$ we are not able to reject the null hypothesis with $95 \%$ confidence, so that the data is normally distributed. If the probability is smaller than 0.05 we can reject the null hypothesis so the data are not distributed normal.

To find the relationship between relationship between hightech exports and patent grants, researchers, R\&D, and FDI the ordinary OLS method was applied to investigate the regression and to find the parameters of the regression. Hence the model is as;

$Y_{i}=\beta_{0}+\beta_{1} X_{1 i}+\beta_{2} X_{2 i}+\beta_{3} X_{3 i}+\beta_{4} X_{4 i}+\varepsilon i$ where $Y$ is the dependent, $\mathrm{X}_{1 \mathrm{i}}, \mathrm{X}_{2 \mathrm{i}}, \mathrm{X}_{3 \mathrm{i}}, \mathrm{X}_{4 \mathrm{i}}$ and $\mathrm{X}_{5 \mathrm{i}}$ are the explanatory variables (or regressors), $\beta_{0}$ is the intercept and $\beta_{1,2,3,4}$ are coefficients of the explanatory variables (slopes), $\varepsilon$ is the stochastic disturbance term for the sample, and $i$ is the $i$ th country in forty-eight countries (Gujarati \& Porter, 2009).

- $\mathrm{Y}_{\mathrm{i}}$ : High-tech exports (million \$, 2020), high-tech exports are calculated by OECD (2011) classification,

- $\mathrm{X}_{1 \mathrm{i}}$ : Total patent grants (direct and PCT national phase entries, resident and abroad, 2020),

- $\mathrm{X}_{2 \mathrm{i}}: \mathrm{R} \& \mathrm{D}$ as a share of GDP $(\%, 2020)$,

- $\mathrm{X}_{3 \mathrm{i}}$ : Researcher per thousand employment,

- $\mathrm{X}_{4 \mathrm{i}}$ : FDI (million \$, inward stock, 2020).

By taking the natural logarithm of the indicator the new model will be as $\ln \left(\mathrm{Y}_{\mathrm{i}}\right)=\beta_{0}+\beta_{1} \ln \left(\mathrm{X}_{1 \mathrm{i}}\right)+\beta_{2} \ln \left(\mathrm{X}_{2 \mathrm{i}}\right)+\beta_{3}$ $\ln \left(X_{3 i}\right)+\beta 4 \ln \left(X_{4 i}\right)+\varepsilon i$.

The regressions above measures the relationship between high-tech exports $(\mathrm{Y})$ and total patent grants $\left(\mathrm{X}_{1}\right)$ and $\mathrm{R} \& \mathrm{D}$ as a share of GDP $\left(\mathrm{X}_{2}\right)$, researcher per thousand employment $\left(\mathrm{X}_{3 \mathrm{i}}\right)$ and FDI $\left(\mathrm{X}_{4 \mathrm{i}}\right)$ are the control variables included in the regression. $\varepsilon$ is the changes in $\mathrm{Y}_{\mathrm{i}}$ which cannot be explained by the model above.

\section{Results and Discussion}

\subsection{Results}

For forty-eight countries, high-tech exports (million \$, 2020), high-tech exports are calculated by OECD (2011) classification, total patent grants (direct and PCT national phase entries, resident and abroad, 2020), R\&D as a share of GDP (\%, 2020), researcher per thousand employment and FDI (million \$, inward stock, 2020) can be seen in Table 1.

In 2020, China has the highest export value as 2.6 trillion dollars. China has 791 billon USD value of high-tech exports as 30.5 percent of the total export. Iceland has the lowest export value as 4.6 billion dollars. Iceland has 57.5 million USD value of hightech exports as 1.5 percent of the total export. Taiwan has 198.7 
billion dollars export value and $57.3 \%$ of them are the high-tech export which makes them top ranked in high-tech export share in total exports. Chile with 428.4 million dollars high-tech exports and $0.63 \%$ share is at the last of the list. In 2020, China has the highest number of patent grants as 485,159 . Costa Rica has the lowest patent grants as 44 . Israel is the top ranked country with $4.93 \%$ R\&D share as a percentage of GDP.
Indonesia has the lowest share as 0.23 . Israel has the highest number of researchers per thousand employment as 17 whereas Colombia has the lowest researcher number as 0.17 . USA has the highest FDI inward stock in the country as 10.8 trillion dollars whereas Iceland has the lowest FDI stock as 7.5 billion dollars.

Table 1. Researchers, R\&D expenditures, patent grants, FDI stock and high-tech exports in OECD countries and emerging markets

\begin{tabular}{|c|c|c|c|c|c|c|}
\hline Country & (1) & (2) & (3) & (4) & (5) & (6) \\
\hline Australia & $9,905.3$ & 3.89 & 6,003 & 1.79 & 9.03 & 790,655 \\
\hline Austria & $23,229.7$ & 14.33 & 9,536 & 3.22 & 11.63 & 194,058 \\
\hline Belgium & $81,365.5$ & 19.40 & 8,687 & 3.17 & 12.39 & 635,929 \\
\hline Canada & $33,622.1$ & 8.62 & 14,046 & 1.70 & 8.80 & $1,099,894$ \\
\hline Chile & 428.3 & 0.63 & 532 & 0.35 & 1.10 & 272,336 \\
\hline Colombia & 571.0 & 1.84 & 357 & 0.32 & 0.17 & 213,323 \\
\hline Costa Rica & 972.3 & 8.36 & 44 & 0.38 & 0.71 & 45,846 \\
\hline Czechia & $41,903.8$ & 21.79 & 1,346 & 1.94 & 7.82 & 188,772 \\
\hline Denmark & $16,482.0$ & 15.37 & 6,998 & 2.91 & 14.89 & 135,125 \\
\hline Estonia & $2,275.9$ & 13.43 & 103 & 1.61 & 7.69 & 34,450 \\
\hline Finland & $5,004.3$ & 7.63 & 8,417 & 2.79 & 14.96 & 96,903 \\
\hline France & $111,225.4$ & 23.36 & 51,169 & 2.20 & 11.05 & 968,138 \\
\hline Germany & $263,546.1$ & 19.12 & 101,453 & 3.19 & 9.96 & $1,059,326$ \\
\hline Greece & $5,022.7$ & 14.32 & 654 & 1.27 & 8.56 & 51,801 \\
\hline Hungary & $25,501.2$ & 21.26 & 726 & 1.48 & 8.33 & 100,993 \\
\hline Iceland & 67.4 & 1.47 & 152 & 2.33 & 10.42 & 7,501 \\
\hline Ireland & $98,201.1$ & 53.33 & 4,006 & 1.23 & 11.37 & $1,350,055$ \\
\hline Israel & $15,484.3$ & 30.88 & 8,674 & 4.93 & 17.00 & 188,952 \\
\hline Italy & $58,272.9$ & 11.75 & 25,755 & 1.47 & 6.31 & 485,842 \\
\hline Japan & $107,863.8$ & 16.83 & 278,935 & 3.20 & 9.85 & 243,046 \\
\hline Korea. Republic of & $172,799.4$ & 33.70 & 151,187 & 4.64 & 15.88 & 264,920 \\
\hline Latvia & $2,365.0$ & 15.58 & 106 & 0.64 & 6.94 & 20,457 \\
\hline Lithuania & $3,016.0$ & 9.18 & 159 & 1.00 & 4.04 & 23,709 \\
\hline Luxembourg & 667.3 & 4.96 & 2,273 & 1.13 & 6.33 & 627,358 \\
\hline Mexico & $76,296.5$ & 18.25 & 1,103 & 0.30 & 1.23 & 596,826 \\
\hline Netherlands & $109,855.7$ & 19.91 & 23,278 & 2.18 & 10.20 & $2,890,579$ \\
\hline New Zealand & 717.2 & 1.91 & 1,311 & 1.41 & 10.75 & 91,463 \\
\hline Norway & $3,971.7$ & 4.82 & 3,912 & 2.15 & 12.65 & 147,764 \\
\hline Poland & $27,528.5$ & 10.83 & 3,609 & 1.32 & 7.38 & 248,732 \\
\hline Portugal & $6,142.2$ & 9.99 & 777 & 1.40 & 10.13 & 183,556 \\
\hline Slovakia & $12,579.6$ & 14.44 & 239 & 0.83 & 6.94 & 63,992 \\
\hline Slovenia & $9,351.9$ & 24.96 & 534 & 2.05 & 10.04 & 20,420 \\
\hline Spain & $27,693.4$ & 8.87 & 5,344 & 1.25 & 7.11 & 853,291 \\
\hline Sweden & $26,933.1$ & 17.31 & 18,855 & 3.39 & 15.14 & 408,824 \\
\hline Switzerland & $124,989.5$ & 39.18 & 28,140 & 3.18 & 9.20 & $1,536,254$ \\
\hline Turkey & $5,670.8$ & 3.34 & 3,244 & 1.09 & 5.58 & 211,573 \\
\hline United Kingdom & $88,284.5$ & 22.31 & 29,178 & 1.76 & 9.68 & $2,206,202$ \\
\hline United States of America (USA) & $261,001.3$ & 18.32 & 306,524 & 3.06 & 9.85 & $10,802,647$ \\
\hline Brazil & $5,432.5$ & 2.60 & 2,859 & 1.16 & 1.80 & 608,086 \\
\hline Russian Federation & $6,201.3$ & 1.84 & 21,311 & 1.04 & 5.57 & 446,656 \\
\hline India & $32,053.2$ & 11.64 & 13,069 & 0.65 & 0.70 & 480,298 \\
\hline Indonesia & $6,763.2$ & 4.14 & 665 & 0.23 & 0.44 & 240,477 \\
\hline China & $791,032.0$ & 30.53 & 485,159 & 2.14 & 2.72 & $1,918,828$ \\
\hline South Africa & $2,024.7$ & 2.36 & 1,023 & 0.83 & 1.83 & 136,735 \\
\hline Malaysia & $95,482.3$ & 40.88 & 1,717 & 1.04 & 4.48 & 174,123 \\
\hline Singapore & $172,443.4$ & 46.12 & 4,088 & 1.84 & 10.57 & $1,855,370$ \\
\hline Taiwan & $198,665.7$ & 57.31 & 13,986 & 3.49 & 13.84 & 109,602 \\
\hline Viet Nam & $111,594.6$ & 39.65 & 194 & 0.53 & 1.18 & 176,911 \\
\hline
\end{tabular}

In Table $\mathbf{1}$ and Table 2 the data sources are as the OECD (2021), the World Bank (2021), TradeMap (2021), the UIS
(2021), TURKSTAT (2021) and the Eurostat (2021b). Heading (1) stands for "high-tech exports (million \$)", (2) for "high-tech 
exports share (\%)", (3) for "total patent grants (direct and PCT national phase entries, resident and abroad)", (4) for "R\&D as a share of GDP (\%)", (5) for "researcher per thousand employment", (6) for "FDI (million \$, stock, 2020)".

In 2020, global high-tech export value was 3.75 trillion dollars. OECD countries have 1.86 trillion dollar high-tech exports, BRRICS countries have 843.5 billon dollars and the EU 979.7 billon dollars high-tech exports. OECD countries have about half of the global high-tech exports by $49.6 \%$, and BRICS countries have $22.3 \%$, BRIICS countries $22.5 \%$, and the EU region by $25.9 \%$ in 2020 .

High-tech export share in total exports was $21.72 \%$ in the world. It was $18.64 \%$ in OECD countries, $23.9 \%$ in BRICS countries, $23 \%$ in BRIICS, and 18.3 in the EU region in 2020. It seems emerging markets have higher share in export of sophisticated products comparing with OECD and the EU countries.

In average, $R \& D$ as a percentage of GDP was $2.2 \%$ in the world, whereas it was $2.5 \%$ in OECD countries, $1.16 \%$ in BRICS countries, $1.01 \%$ in BRIICS, and 2.12 in the EU region in 2020. It seems the OECD and the EU countries have higher share of R\&D in their GDP comparing with emerging markets.

Global FDI inward stock was 41.4 trillion dollars and $71 \%$ of the global FDI so that 29.4 trillion dollars was in OECD countries. EU has the $33.2 \%$ percent of the global FDI stock as 13.7 trillion dollars. BRIICS countries have 3.8 trillion dollars FDI stock and this value was $9.3 \%$ of the global stock.

Number of researchers per thousand employment was 2.20 in the world, 2.48 in OECD countries, and 1.01 in BRIICS countries and 2.12 in the EU region. OECD countries have higher researcher per thousand employment than BRIICS countries.

In average, $R \& D(\%$ of GDP) was $2.2 \%$ in the world, whereas it was $2.5 \%$ in OECD countries, $1.16 \%$ in BRICS countries, $1.01 \%$ in BRIICS, and 2.12 in the EU region in 2020. It seems that, the OECD and the EU countries have higher share of R\&D in their GDP comparing with emerging markets (Table 2).

Table 2. Regional researchers, $R \& D$ expenditures, patent grants, FDI stock and high-tech exports

\begin{tabular}{|l|c|c|c|c|c|c|}
\hline Country & $(1)$ & $(2)$ & $(3)$ & $(4)$ & $(5)$ & $(6)$ \\
\hline BRICS & $836,743.7$ & 23.92 & 523,421 & 1.16 & 2.52 & $3,590,603$ \\
\hline BRIICS & $843,506.9$ & 23.04 & 524,086 & 1.01 & 2.18 & $3,831,081$ \\
\hline Others & $468,924.8$ & 19.62 & 27,267 & & & $5,845,647$ \\
\hline World & $3,751,426.2$ & 21.72 & $1,663,001$ & 2.20 & 2.84 & $41,354,249$ \\
\hline OECD & $1,860,808.4$ & 18.64 & $1,107,366$ & 2.48 & 8.90 & $29,361,513$ \\
\hline European Union & $970,717.5$ & 18.32 & 275,443 & 2.12 & 8.87 & $13,737,533$ \\
\hline OECD & $1,860,808.4$ & 18.64 & $1,107,366$ & 2.48 & 8.90 & $29,315,668$ \\
\hline
\end{tabular}

\section{Normality of the data}

For testing the normality of the data, the hypotheses are as:

$\mathrm{H}_{0}$ : The data set statistically distributed normal

$\mathrm{H}_{1}$ : The data set statistically distributed not normal

For the data with natural logarithm Shapiro-Wilk test results show that high-tech exports, total patent grants and FDI data are normally distributed ( $p$ values are greater than the critical value 0.05 so that we are not able to reject null hypothesis) whereas researcher per thousand employment and R\&D expenditure as a share of GDP are not normally distributed ( $p$ values are smaller than the critical value 0.05 so that we reject null hypothesis and accept alternative one) (Table 3). As mentioned above, according to the results of the normality tests, parametric tests should be applied for the normally distributed data set and non-parametric tests should be used for non-normally distributed data set especiallt to check the correlations between indicators.

Table 3. Normality tests of the raw data and data with natural logarithm (p values) IBM (2021a) and Eviews (2021)

\begin{tabular}{|c|c|}
\hline Raw data & Natural logarithm \\
\hline
\end{tabular}

\begin{tabular}{|l|c|c|c|c|c|c|}
\cline { 1 - 6 } Indicator & KS test & $\begin{array}{l}\text { SW } \\
\text { test }\end{array}$ & $\begin{array}{c}\text { JB } \\
\text { test }\end{array}$ & KS test & $\begin{array}{c}\text { SW } \\
\text { test }\end{array}$ & $\begin{array}{c}\text { JB } \\
\text { test }\end{array}$ \\
\hline $\begin{array}{l}\text { High-tech } \\
\text { exports }\end{array}$ & 0.000 & 0.000 & 0.000 & 0.200 & 0.240 & 0.374 \\
\hline $\begin{array}{l}\text { Total patent } \\
\text { grants }\end{array}$ & 0.000 & 0.000 & 0.000 & 0.200 & 0.770 & 0.697 \\
\hline $\begin{array}{l}\text { R\&D as a } \\
\text { share of } \\
\text { GDP }\end{array}$ & 0.095 & 0.012 & 0.093 & 0.200 & 0.035 & 0.151 \\
\hline $\begin{array}{l}\text { Researcher } \\
\text { per } \\
\text { thousand } \\
\text { employment }\end{array}$ & 0.200 & 0.084 & 0.523 & 0.000 & 0.000 & 0.000 \\
\hline FDI & 0.000 & 0.000 & 0.000 & 0.200 & 0.955 & 0.971 \\
\hline
\end{tabular}

\section{Correlations between the indicators}

As the high-tech exports, total patent grants and FDI data are normally distributed so that parametric correlation test (Pearson Correlation statistic) can be applied for these data. Researcher per thousand employment and R\&D expenditure as a share of GDP are not normally distributed data so that nonparametric correlation test (Spearman's rho) can be applied for these data.

According to the correlation tests analysis with the crosssection data for forty-eight countries R\&D expenditures, patents and FDI have high positive effect on high-tech exports and there is a low positive relationship with high-tech exports 
and researchers. There is a high positive correlation between patents and high-tech exports, R\&D, researchers and FDI. There is a high positive correlation between $R \& D$ and high-tech exports, patents and researchers and low positive correlation with FDI. There is a high positive correlation between researchers and patents whereas low positive correlation with high-tech exports. FDI is highly positive correlated with patents

(Table 4).

\section{Table 4. Correlation coefficients of the data (natural} logarithm) (IBM, 2021a)

\begin{tabular}{|l|c|c|c|c|c|}
\hline & High- & $\begin{array}{l}\text { Total } \\
\text { tech } \\
\text { patent } \\
\text { exports } \\
\text { grants }\end{array}$ & $\begin{array}{l}\text { as a } \\
\text { share } \\
\text { of } \\
\text { GDP }\end{array}$ & $\begin{array}{l}\text { Researcher } \\
\text { per } \\
\text { thousand } \\
\text { employment }\end{array}$ & FDI \\
\hline $\begin{array}{l}\text { Indicator } \\
\text { exports }\end{array}$ & 1,000 & 0,701 & 0,460 & 0,270 & 0,643 \\
\hline $\begin{array}{l}\text { Total patent } \\
\text { grants }\end{array}$ & 0,701 & 1,000 & 0,651 & 0,432 & 0,722 \\
\hline $\begin{array}{l}\text { R\&D as a } \\
\text { share of } \\
\text { GDP }\end{array}$ & 0,460 & 0,651 & 1,000 & 0,854 & 0,187 \\
\hline $\begin{array}{l}\text { Researcher } \\
\text { per } \\
\text { thousand } \\
\text { employment }\end{array}$ & 0,270 & 0,432 & 0,854 & 1,000 & 0,025 \\
\hline FDI & 0,643 & 0,722 & 0,187 & 0,025 & 1,000 \\
\hline
\end{tabular}

\section{Causality in data set}

For causality analysis of raw data with Granger causality test it is seen that only researchers does Granger cause R\&D (Hata! Başvuru kaynağı bulunamad1.). For Toda Yamamota causality test (Wald test) patents and FDI cause high-tech exports. R\&D and researchers cause patents too. It can be said that researchers and R\&D end up with patent grants and patents will cause an increase in high-tech exports.

For causality analysis of natural logarithm taken data with Granger causality test it is seen that none of the indicators does Granger cause the others (Hata! Başvuru kaynağı bulunamadı.). For Toda Yamamota causality test (Wald test) researchers, R\&D, patents and FDI cause high-tech exports. R\&D and researchers cause patents too. It can be said that researchers, R\&D end up with patent grants and patents with FDI will cause an increase in high-tech exports.

In the study, the relationship between high-tech exports, R\&D and patents for OECD and ten emerging countries was analysed and it is seen that both groups have different results. In OECD countries patents have a higher positive correlation with high-tech exports than ten emerging countries group. In ten emerging countries group $\mathrm{R} \& \mathrm{D}$ have a higher positive correlation with high-tech exports than OECD countries. As a result, in both country groups patent grants and R\&D expenditures have positive effect on high-tech exports.

Table 5. Causality test results of the data (raw and natural logarithm) by Granger test (Eviews, 2021),

\begin{tabular}{|c|c|c|}
\hline Null Hypothesis: & $\begin{array}{l}\text { Raw } \\
\text { data }\end{array}$ & $\begin{array}{c}\text { Data } \\
\text { with } \\
\text { natural }\end{array}$ \\
\hline
\end{tabular}

\begin{tabular}{|l|c|c|}
\hline & $\begin{array}{c}\text { (probabil } \\
\text { ity) }\end{array}$ & $\begin{array}{c}\text { logarith } \\
\text { m (ln) } \\
\text { (probabil } \\
\text { ity) }\end{array}$ \\
\hline $\begin{array}{l}\text { High-tech export does not Granger } \\
\text { Cause FDI }\end{array}$ & 0,683 & 0,269 \\
\hline $\begin{array}{l}\text { FDI does not Granger Cause High- } \\
\text { tech export }\end{array}$ & 0,853 & 0,897 \\
\hline Patent does not Granger Cause FDI & 0,593 & 0,424 \\
\hline FDI does not Granger Cause Patent & 0,988 & 0,840 \\
\hline R\&D does not Granger Cause FDI & 0,680 & 0,890 \\
\hline FDI does not Granger Cause R\&D & 0,515 & 0,227 \\
\hline $\begin{array}{l}\text { Researcher does not Granger Cause } \\
\text { FDI }\end{array}$ & 0,692 & 0,946 \\
\hline $\begin{array}{l}\text { FDI does not Granger Cause } \\
\text { Researcher }\end{array}$ & 0,389 & 0,193 \\
\hline $\begin{array}{l}\text { Patent does not Granger Cause High- } \\
\text { tech export }\end{array}$ & 0,820 & 0,893 \\
\hline $\begin{array}{l}\text { High-tech export does not Granger } \\
\text { Cause Patent }\end{array}$ & 0,636 & 0,810 \\
\hline $\begin{array}{l}\text { R\&D does not Granger Cause High- } \\
\text { tech export }\end{array}$ & 0,471 & 0,890 \\
\hline $\begin{array}{l}\text { High-tech export does not Granger } \\
\text { Cause R\&D }\end{array}$ & 0,342 & 0,096 \\
\hline $\begin{array}{l}\text { Researcher does not Granger Cause } \\
\text { High-tech export }\end{array}$ & 0,237 & 0,628 \\
\hline $\begin{array}{l}\text { High-tech export does not Granger } \\
\text { Cause Researcher }\end{array}$ & 0,384 & 0,420 \\
\hline R\&D does not Granger Cause Patent \\
\hline Patent does not Granger Cause R\&D \\
\hline $\begin{array}{l}\text { Researcher does not Granger Cause } \\
\text { Patent }\end{array}$ & 0,257 & 0,163914 \\
\hline $\begin{array}{l}\text { Patent does not Granger Cause } \\
\text { Researcher }\end{array}$ & 0,238 \\
\hline $\begin{array}{l}\text { Researcher does not Granger Cause } \\
\text { R\&D }\end{array}$ & 0,1025 \\
\hline R\&D does not Granger Cause & 0,988 \\
\hline
\end{tabular}

The relationship between high-tech exports and patents, researchers, $R \& D$, and FDI by $O L S$ estimation

In the study the relationship between high-tech exports and patent grants, researchers, R\&D, and FDI was estimated by descriptive statistics and OLS regression. The results were also investigated by scatter diagram.

The model for the raw data which was obtained by OLS is as;

$Y_{i}=32,845.6+1.167\left(X_{1 i}\right)+7.99\left(X_{2 i}\right)+2,105.7\left(X_{3 i}\right)-0.003\left(X_{4 i}\right)$

where all probability of the coefficients rather than patents of the regressors are greater than 0.05 critical value so that relationship is not significant. The coefficient of the patent explanatory variable is smaller than 0.05 so that we can say there is positive relationship between high-tech exports and patent grants. The OLS results does not show a significant relationship between high-tech exports and R\&D expenditures, researches, patents and FDI in total but high-tech exports have positive relationship with patents, and FDI (coefficients are statistically significant) where no relationship with $R \& D$ 
expenditures and researcher (coefficients are not statistically significant) (Table 6).

By taking the natural logarithm of the indicator the new model will be as;

$\ln \left(Y_{i}\right)=7.30+0.37 \ln \left(X_{1 i}\right)+0.05 \ln \left(X_{2 i}\right)+0.186 \ln \left(X_{3 i}\right)+0.48 \ln \left(X_{4 i}\right)$ where all probability of the coefficients of the regressors are greater than 0.05 critical value so that relationship is not significant. When bilateral relationship between high-tech exports and patents, R\&D expenditures and FDI, it can be seen that there is a positive relationship between high-tech exports and patents, R\&D expenditures and FDI (coefficients of the three indicators are statistically significant) where no relationship with researchers (coefficient is not statistically significant).

Table 6. The relationship between high-tech exports and patent grants, researchers, $R \& D$, and FDI (Eviews, 2021),

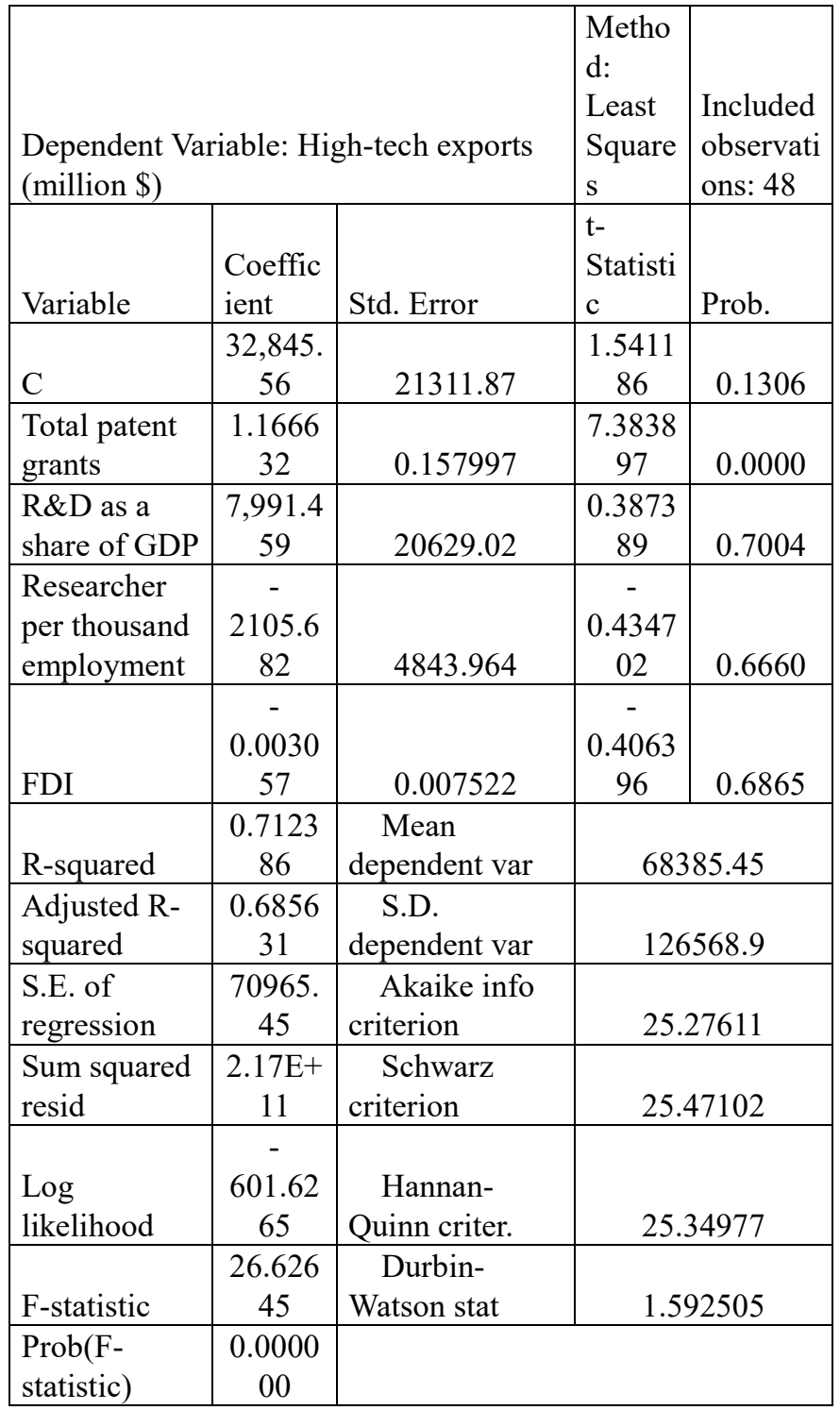

\section{The relationship between high-tech exports and patents, researchers, $R \& D$, and FDI by graphs}

If the relationship between high-tech exports and patents is wanted to be analysed by the graph, the result will be as below. About $49.2 \%$ of the changes in high-tech exports was explained by the patents Graph of the relationship between high-tech exports and patents shows that there is a positive correlation between two indicators (Graph 1).

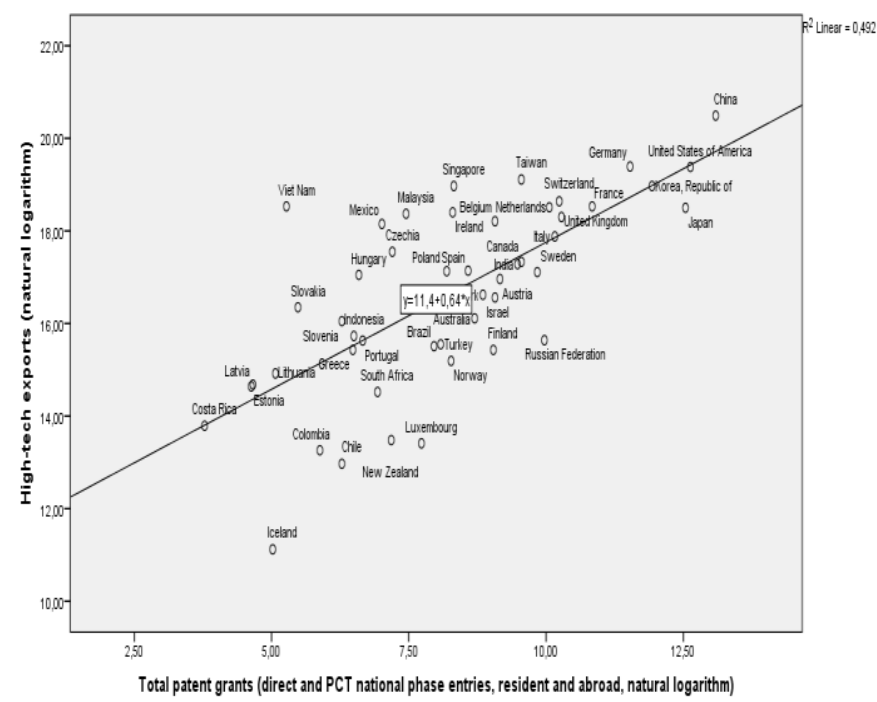

Graph 1. The relationship between high-tech exports and patents (IBM, 2021a)

If the relationship between high-tech exports and R\&D expenditures as a share of GDP is wanted to be analysed by the graph, the result will be as below. About $17.2 \%$ of the changes in high-tech exports was explained by the patents Graph of the relationship between high-tech exports and $R \& D$ expenditures as a share of GDP shows that there is a positive correlation between two indicators (Hata! Başvuru kaynağı bulunamadı.).

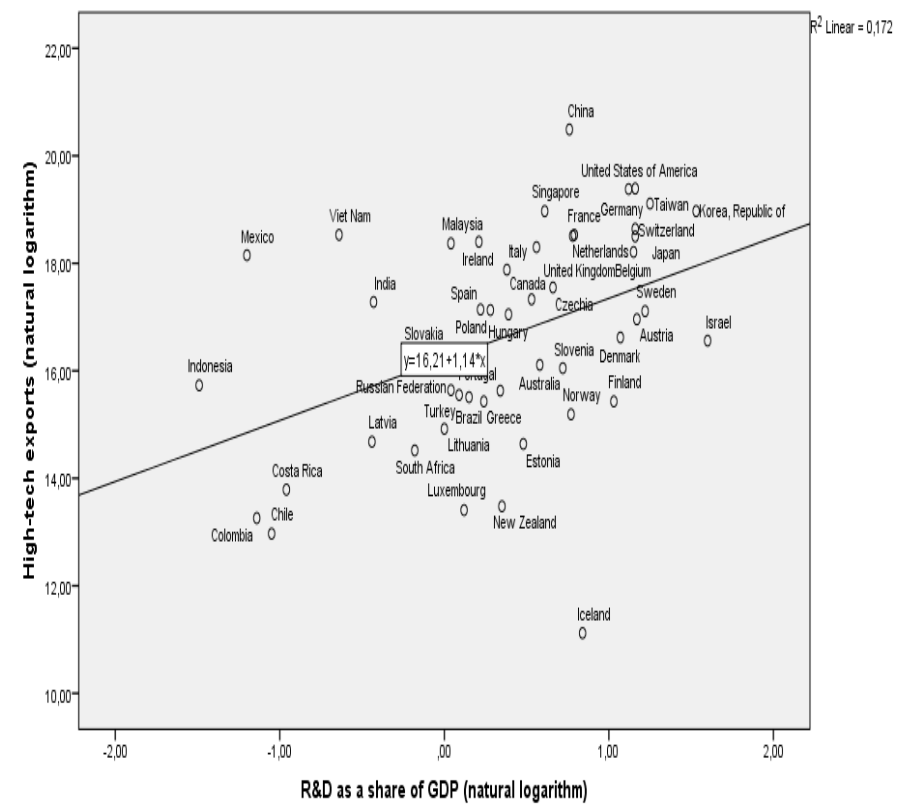

Graph 2. The relationship between high-tech exports and $R \& D$ expenditures (IBM, 2021a)

If the relationship between high-tech exports and researcher per thousand employment is wanted to be analysed by the graph, the result will be as below. About $8.1 \%$ of the changes in high-tech exports was explained by the patents Graph of the relationship between high-tech exports and researcher per thousand employment shows that there is a positive correlation between two indicators (Graph 3). 


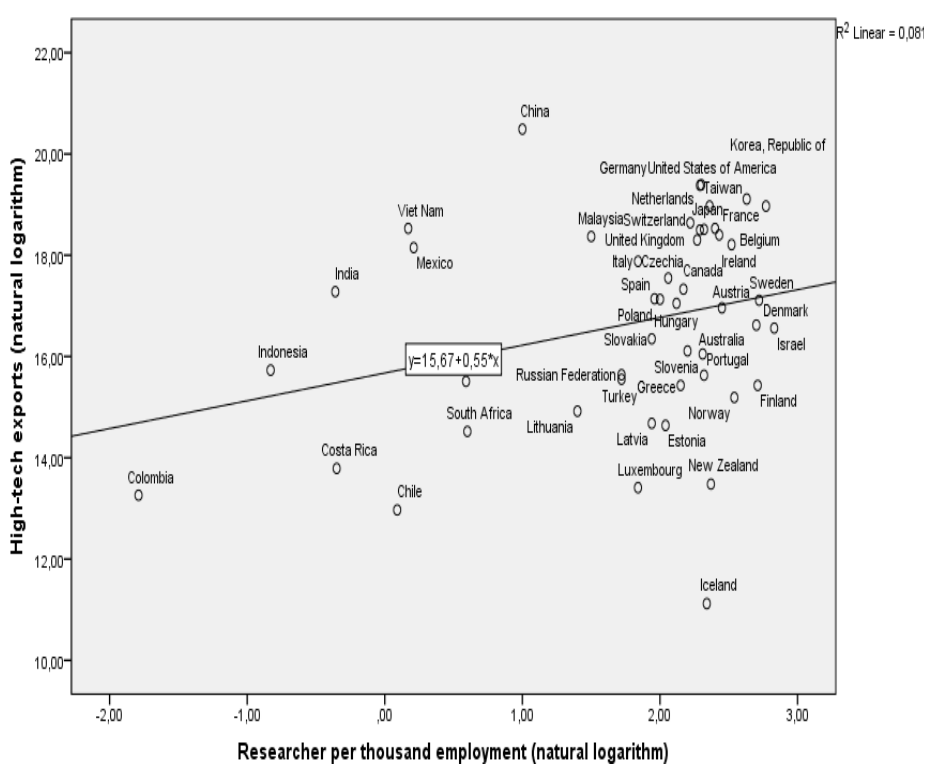

Graph 3. The relationship between high-tech exports and researchers (IBM, 2021a)

If the relationship between high-tech exports and researcher per thousand employment is wanted to be analysed by the graph, the result will be as below. About $41.4 \%$ of the changes in high-tech exports was explained by the patents Graph of the relationship between high-tech exports and researcher per thousand employment shows that there is a positive correlation between two indicators (Graph 4).

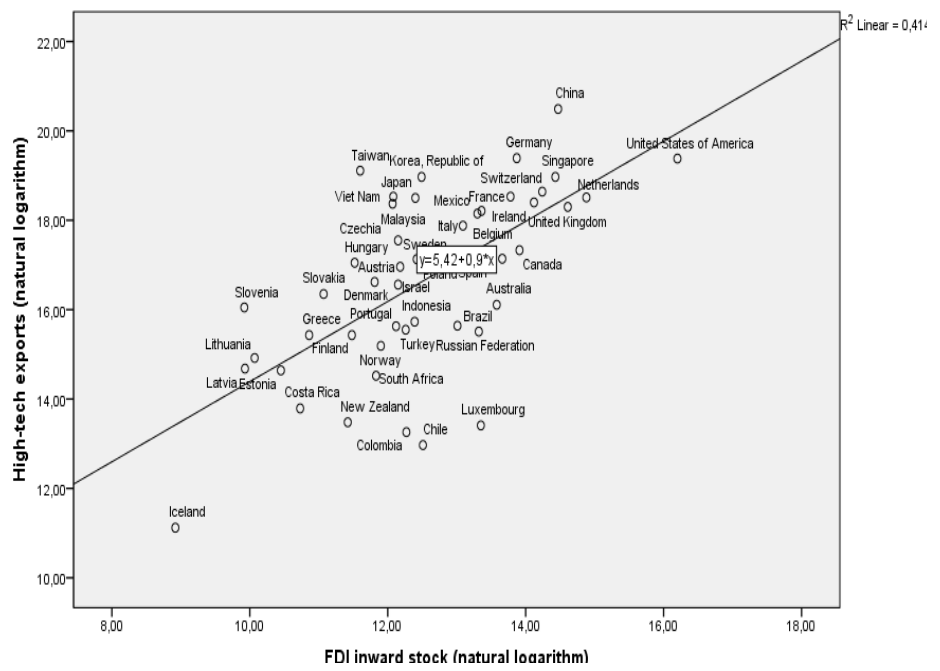

Graph 4. The relationship between high-tech exports and FDI (IBM, 2021a)

\subsection{Discussion}

The pandemic has negatively affected global supply chains and value chains in 2020. Technological improvements in medicine and R\&D on vaccines ended with good results so that even not equally but vaccination has spread all over the world. Closures and lockdowns have loosened and global economy has started to recover the lost.

The annualized global exports have reached to about 21 trillion dollars by the 3 rd quarter of 2021 with a growth rate of $24.1 \%$ comparing with the same period in 2020 (WTO, 2021).
For the first time quarterly global trade exceed 5 trillion dollars in 2021 and for the first three quarters in 2021 global exports have increased $28.3 \%$ comparing with 2020. WIPO (2021d) stated that total as the global economy slowed down, especially the transport and construction sectors merchandise trade fell by 9.2\% to USD17.1 trillion in 2020 from USD18.9 trillion in 2019. Actually global exports have contracted $7.17 \%$ in 2020 comparing with 2019 from 18.8 trillion dollars to 17.4 trillion dollars (WTO, 2021).

In the study it is found that global high-tech exports have increased by $0.2 \%$ in 2020 to 3.74 trillion dollars, as WIP0 (2021) expected early in 2021 to decline about $1 \%$ as compared to 2019 and to USD3.36 trillion in 2020 .

In this study, it is found that for the country group of OECD and ten emerging markets patents played a crucial role for hightech export. In their study, Bayraktutan and Bidırdı (2018) concluded that patents are one of the key determinants of hightech exports in both developed and developing countries for the period of 1996-2012.

In the study, the relationship between patents and high tech exports was investigated and a positive relationship was found. R\&D expenditure are also positively related with patents. Durmaz and Yildiz (2020) have found that there is a significant positive relationship between the number of patents and hightech exports in the BRICS countries. They also stated the importance of innovation in the export of high-tech products for the countries.

In the study, the relationship between high-tech exports, R\&D and patents for OECD and ten emerging countries was analysed individually and it is seen that both groups have different results. In OECD countries patents have a higher positive correlation with high-tech exports than ten emerging countries group. In ten emerging countries group R\&D have a higher positive correlation with high-tech exports than OECD countries. As a result, in both country groups patent grants and $\mathrm{R} \& \mathrm{D}$ expenditures have positive effect on high-tech exports.

\section{Conclusions}

- In 2021, it is seen that the effect of the pandemic was overtaken, the global value chain has increased again with the formation of alternative global supply chains, and as a result, global trade also has increased and passed even the pre-pandemic period value.

- For the first time quarterly global trade exceed 5 trillion dollars in 2021 and for the first three quarters in 2021 global exports have increased $28.3 \%$ comparing with 2020 .

- Contrary to all worse expectations, hightechnology products have increased by $0.2 \%$ in 2020 to 3.74 trillion dollars.

- OECD countries have about half of the global high-tech exports by $49.6 \%$, and BRICS countries have $22.3 \%$, BRIICS countries $22.5 \%$, and the EU region by $25.9 \%$ in 2020 .

- High-tech export share in total exports was $21.72 \%$ in the world, whereas it was $18.64 \%$ in OECD countries, $23.9 \%$ in BRICS countries, $23 \%$ in BRIICS, 
and 18.3 in the EU region in 2020. It seems emerging markets have higher share in export of sophisticated products comparing with OECD and the EU countries.

- In average, R\&D as a percentage of GDP was $2.2 \%$ in the world, whereas it was $2.5 \%$ in OECD countries, $1.16 \%$ in BRICS countries, $1.01 \%$ in BRIICS, and 2.12 in the EU region in 2020. It seems the OECD and the EU countries have higher share of $\mathrm{R} \& \mathrm{D}$ in their GDP comparing with emerging markets.

- High-tech exports are highly positive correlated with patents, FDI and R\&D expenditures.

- OECD countries have higher positive correlation between high-tech exports and patents than emerging countries.

- Emerging countries have higher positive correlation between high-tech exports and R\&D expenditures than OECD countries.

- Patents are highly positive correlated with high-tech exports, $R \& D$ expenditures, researcher number (per thousand labour employment) and FDI. As the countries are more globalized by FDI, an increase in $R \& D$ results with increase in patent grants and high-tech exports in international markets.

- The lack of capital is being compensated by FDI in emerging markets, and R\&D expenditures with researchers are main inputs of innovative production so that it ends up with high-tech exports in international markets.

\section{References}

Aghion, P., \& Howitt, P. (1992). A Model of Growth Through Creative Destruction. Econometrica, 60(2), 323-351. https://doi.org/10.2307/2951599 Retrieved from: http://individual.utoronto.ca/zheli/A3.pdf (accessed: December 27, 2021)

Bayraktutan, Y. and B1dırd1, H. (2018). Innovation and HighTech Exports in Developed and Developing Countries. Journal of International Commerce, Economics and Policy, 9(03), 1850011. DOI: 10.1142/S1793993318500114

Durmaz, A. \& Yildız, Ü. (2020). The Impact of Innovation in The Process of High Technology Exports: An Analysis on BRICS Countries. Uluslararası İktisadi ve İdari İncelemeler Dergisi, (28), 193-202. DOI: 10.18092/ulikidince. 734893

Eurostat (2021a). Glossary: High-tech classification of manufacturing industries. Retrieved from: https://ec.europa.eu/eurostat/statisticsexplained/index.php?title=Glossary:Hightech_classification_of_manufacturing_industries (accessed: December 27,2201 )

Eurostat (2021b). Science, technology and innovation Overview. Retrieved from: https:/ec.europa.eu/eurostat/web/science-technologyinnovation/overview (accesses: December 27, 2021)

Eviews (2021). Innovative Solutions for econometric analysis, forecasting \& simulation. Retrieved from: https://www.eviews.com/home.html (Accessed: December 26, 2021)
Gujarati, D. N. \& Porter, D.C. (2009), Basic Econometrics. McGraw-Hill/Irwin, 5th edition, p. 98.\& p.888. Retrieved from:

https://cbpbu.ac.in/userfiles/file/2020/STUDY_MAT/ECO /1.pdf (Accessed: 26 December, 2021)

Gürler, M. (2016). Rekabetçiliğin Orta Gelir Tuzağından Çıkıştaki Etkisi: Türkiye Analizi, Doktora Tezi, Marmara Üniversitesi Sosla Bilimler Enstitüsü, İstanbul, Türkiye. Retrieved from: https://tez.yok.gov.tr/UlusalTezMerkezi/TezGoster?key=B r_XTptK8CZ70f0JGX9xElMxSRn6vvzfG2ieGoPn1cC86 ezAG3-IOuIswc7Uvmww (accessed: December 27, 2021)

Hatzichronoglou, T. (1997). Revision of the High-Technology Sector and Product Classification. OECD Science, Technology and Industry Working Papers 1997/02. Retrieved from: https:/www.oecdilibrary.org/docserver/134337307632.pdf?expires $=164058$ 6760\&id $=$ id\&accname $=$ guest\&checksum $=29287$ D3EE51 BE8A3131755DACDE0B2B0 (accessed: December 27, 2021)

IBM (2021a). IBM SPSS Statistics. https://www.ibm.com/products/spss-statistics (Accessed: December 26, 2021)

IBM (2021b). IBM Db2 Warehouse on Cloud/Statisticsparametric and nonparametric. Retrieved from: https://www.ibm.com/docs/vi/db2woc?topic=proceduresstatistics-parametric-nonparametric (accessed: December 26, 2021)

Minitab. 2015. Choosing Between a Nonparametric Test and a Parametric Test. Retrieved from: https://blog.minitab.com/en/adventures-in-statistics2/choosing-between-a-nonparametric-test-and-aparametric-test (accessed: December 26, 2021)

Mishra, P., C. M. Pandey, U. Singh, A. Gupta, C. Sahu, and A. Keshri. 2019. Descriptive statistics and normality tests for statistical data. Annals of cardiac anaesthesia. 22/1: 67-72. Retrieved from: https://doi.org/10.4103/aca.ACA_157_18 (accessed: December 26, 2021)

OECD (2009). OECD Science, Technology and Industry Scoreboard 2009: R\&D Growth over the business cycle. Retrieved from: https:/www.oecdilibrary.org/docserver/sti_scoreboard-2009en.pdf? expires $=1640620294 \& \mathrm{id}=\mathrm{id} \&$ accname $=$ guest $\&$ che cksum=4F7D91ED83A2B0CF8BF0AF61643DEC71 (accessed: December 27, 2021)

OECD (2011). ISIC REV. 3 TECHNOLOGY INTENSITY DEFINITION/Classification of manufacturing industries into categories based on R\&D intensities. Retrieved from: https://www.oecd.org/sti/ind/48350231.pdf (accessed: December 27, 2021)

OECD (2017). OECD Science, Technology and Industry Scoreboard 2017: The Digital Transformation. Retrieved from: https://www.oecdilibrary.org/docserver/9789264268821 en.pdf? expires $=1640619836 \& \mathrm{id}=\mathrm{id} \&$ accname $=$ guest\&che cksum $=788$ D353E1162D7963377302FF8BEE9F0 (accessed: December 27, 2021)

OECD (2021). OECD statistics. Retrieved from: https://stats.oecd.org/ (accessed: December 27, 2021)

Schumpeter, J. A. (1942). Capitalism, Socialism and Democracy. Swedberg, R. (ed). Taylor \& Francis e-Library, 2003. Retrieved from: https://eet.pixelonline.org/files/etranslation/original/Schumpeter,\%20Capi 
talism,\%20Socialism\%20and\%20Democracy.pdf

(accessed: December 27, 2021)

The UNESCO Institute for Statistics (UIS) (2021). UIS statistics. Retrieved from: http://data.uis.unesco.org/ (accessed: December 27, 2021)

The World Bank (2021a). TCdata360. High-technology exports (\% of manufactured exports). Retrieved from: https://tcdata360.worldbank.org/indicators/mnfc.TX.VAL. TECH.MF.ZS? country $=$ BRA\&indicator $=2010 \& v i z=$ line chart\&years=1988,2019 (accessed: December 27, 2021)

The World Bank (2021b). Data. Retrieved from: https://data.worldbank.org/ (accessed: December 27, 2021)

TradeMap. Statistics Data. Retrieved from: https://www.trademap.org/Country_SelProduct_TS.aspx? nvpm $=1 \% 7 \mathrm{c} \% 7 \mathrm{c} \% 7 \mathrm{c} \% 7 \mathrm{c} \% 7 \mathrm{cTOTAL} \% 7 \mathrm{c} \% 7 \mathrm{c} \% 7 \mathrm{c} 2 \% 7 \mathrm{c}$ $1 \% 7 \mathrm{c} 1 \% 7 \mathrm{c} 1 \% 7 \mathrm{c} 2 \% 7 \mathrm{c} 1 \% 7 \mathrm{c} 2 \% 7 \mathrm{c} 1 \% 7 \mathrm{c} \% 7 \mathrm{c} 1$ (accessed: December 31, 2021)

Turkish Statistic Institute (TURKSTAT) (2021). Research and Development Activities Survey, 2020. Retrieved from: https://data.tuik.gov.tr/Bulten/Index?p=Research-andDevelopment-Activities-Survey-2020-37439

World Economic Forum (WEF) (2006). The Global Competitiveness Report 2006-2007. Retrieved from: https://www3.weforum.org/docs/WEF_GlobalCompetitiv enessReport 2006-07.pdf (accessed: December 27, 2021)

WEF (2017). The Global Competitiveness Report 2017-2018. Methodology and Computation of the Global Competitiveness Index 2017-2018. Retrieved from: https://www3.weforum.org/docs/GCR2017-

2018/05FullReport/TheGlobalCompetitivenessReport201 7\%E2\%80\%932018.pdf (accessed: December 27, 2021)

World Intellectual Property Organization (WIPO) (2021a). What is patent? Retrieved from: https://www.wipo.int/patents/en/ (accessed: December 27, 2021)

WIPO (2021b). Patent Cooperation Treaty Yearly Review 2021: The International Patent System. Retrieved from: https://www.wipo.int/edocs/pubdocs/en/wipo_pub_901_2 021.pdf (accessed: December 27, 2021)

WIPO (2021c). WIPO IP Statistics Data Center. Retrieved from: https://www3.wipo.int/ipstats/ (accessed: December 27, 2021)

WIPO (2021d). High-Tech Trade Rebounded Strongly in the Second Half of 2020, with New Asian Exporters Benefiting. Retrieved from: https://www.wipo.int/pressroom/en/news/2021/news_000 1.html (accessed: December 26, 2021).

World Trade Organization (WTO) (2021). Documents, data and resources. WTO Data Portal. Retrieved from: https://www.wto.org/english/res_e/statis_e/statis_e.htm (accessed: December 26, 2021).

Yeldan, E., Taşçı, K., Voyvoda E. and Özsan, M. E., (2012). Orta Gelir Tuzağından Çıkış: Hangi Türkiye? Vol. 1: Makro/Bölgesel/Sektörel Analiz. İstanbul: Türk Girişim ve İş Dünyası Konfederasyonu (Türkonfed). Retrieved from: https://turkonfed.org/Files/ContentFile/ogt-raporu-iicilt.pdf (accessed: December 27, 2021) 